\title{
Dipeptidyl peptidase IV (CD26) activity in the hematopoietic system: differences between the membrane-anchored and the released enzyme activity
}

\author{
D.A. Pereira ${ }^{1,2}$, \\ L. Gomes ${ }^{2,3}$, \\ M.C. El-Cheikh² \\ and R. Borojevic ${ }^{2,4}$
}

\author{
1Divisão de Farmacologia, Coordenação de Pesquisa, Instituto Nacional do Câncer, \\ Rio de Janeiro, RJ, Brasil \\ ${ }^{2}$ Departamento de Histologia e Embriologia, Instituto de Ciências Biomédicas, \\ Universidade Federal do Rio de Janeiro, Rio de Janeiro, RJ, Brasil \\ ${ }^{3}$ Departamento de Biologia Celular, Instituto de Biologia, Universidade Estadual \\ de Campinas, Campinas, SP, Brasil \\ ${ }^{4}$ Programa Avançado de Biologia Celular Aplicada à Medicina, \\ Hospital Universitário Clementino Fraga Filho, \\ Universidade Federal do Rio de Janeiro, Rio de Janeiro, RJ, Brasil
}

\section{Correspondence}

R. Borojevic

Caixa Postal 68021

21941-970 Rio de Janeiro, RJ

Brasil

Fax: +55-21-2562-6483

E-mail: Radovan@iq.ufrj.br

Publication of the Millennium Institute of Tissue Bioengineering. Research supported by the National Cancer Institute, Rio de Janeiro (PROFIP-INCA), PRONEX, FINEP, CNPq and FAPERJ.

Publication supported by FAPESP.

Received June 25, 2002

Accepted December 2, 2002

\begin{abstract}
Dipeptidyl peptidase IV (DPP-IV; CD26) (EC 3.4.14.5) is a membrane-anchored ectoenzyme with $\mathrm{N}$-terminal exopeptidase activity that preferentially cleaves X-Pro-dipeptides. It can also be spontaneously released to act in the extracellular environment or associated with the extracellular matrix. Many hematopoietic cytokines and chemokines contain DPP-IV-susceptible N-terminal sequences. We monitored DPP-IV expression and activity in murine bone marrow and liver stroma cells which sustain hematopoiesis, myeloid precursors, skin fibroblasts, and myoblasts. RT-PCR analysis showed that all these cells produced mRNA for DPP-IV. Partially purified protein reacted with a commercial antibody to CD26. The $K_{\mathrm{M}}$ values for GlyPro-p-nitroanilide ranged from 0.43 to $0.98 \mathrm{mM}$ for the membraneassociated enzyme of connective tissue stromas, and from 6.76 to 8.86 $\mathrm{mM}$ for the enzyme released from the membrane, corresponding to a ten-fold difference, but only a two-fold difference in $K_{\mathrm{M}}$ was found in myoblasts. $K_{\mathrm{M}}$ of the released soluble enzyme decreased in the presence of glycosaminoglycans, nonsulfated polysaccharide polymers $(0.8-10 \mu \mathrm{g} / \mathrm{ml})$ or simple sugars $(320-350 \mu \mathrm{g} / \mathrm{ml})$. Purified membrane lipid rafts contained nearly $3 / 4$ of the total cell enzyme activity, whose $K_{\mathrm{M}}$ was three-fold decreased as compared to the total cell membrane pool, indicating that, in the hematopoietic environment, DPP-IV activity is essentially located in the lipid rafts. This is compatible with membrane-associated events and direct cell-cell interactions, whilst the long-range activity depending upon soluble enzyme is less probable in view of the low affinity of this form.
\end{abstract}

Key words

- Hematopoiesis

- Stroma

- Exopeptidase

- Ectoenzyme

- Membrane rafts 


\section{Introduction}

Dipeptidyl peptidase IV (DPP-IV) (EC 3.4.14.5) is a member of the serine peptidase family, which cleaves N-terminal X-Prodipeptides from peptides and proteins. It is expressed in several tissues, with the highest levels being in kidney and small intestine, and lower ones in lungs, liver and spleen (1). It is an ectoenzyme frequently present on the apical surface of epithelial cells (2), and it is also present in connective tissue cells, in soluble form and/or associated with the surrounding extracellular matrix (3).

DPP-IV was originally described and characterized in liver and kidney (4). Later, the CD26 glycoprotein, characterized as a T cell differentiation or activation marker, was shown to be identical to DPP-IV (5). The mechanism of CD26-mediated lymphocyte stimulation has been ascribed in part to its association with CD45 and an increase of tyrosine phosphorylation in signal transduction pathways, including activation of mitogen-activated protein kinase (6,7). CD26 was later recognized to be identical to another relevant molecule in the immune system, i.e., the adenosine deaminase complexing protein. Binding to adenosine deaminase does not require the DPP-IV enzymatic activity and is involved in immunoregulatory mechanisms through the control of adenosine-mediated inhibition of lymphocyte interleukin-2 (IL-2) production and proliferation (8).

Parallel studies of the lymphohematopoietic system have shown that, in addition to the control of activation and proliferation of T cells, CD26 has a co-stimulating activity for proliferation of granulocytes and macrophages (9). Inhibition of the DPP-IV enzymatic activity was reported to increase granulocyte-macrophage colony formation as well as immature thymocyte proliferation (10). These data contrast with the reported increase of IL-2 production associated with increased DPP-IV activity in mitogen-stimulated $\mathrm{T}$ cells (11), and the decrease of IL-2 production and antigen-stimulated proliferation of peripheral $\mathrm{T}$ cells caused by DPP-IV inhibitors (12).

Biological activities that have been proposed for DPP-IV include degradation of denatured collagen, intestinal and renal handling of proline-containing peptides, as well as metabolism of neuropeptides and glucagon-like peptides $(13,14)$. Many cytokines involved in hematopoiesis, such as IL-1ß, IL-2, IL-3, IL-5, IL-6, IL-8, IL-10, IL-13, granulocyte-macrophage colonystimulating factor, granulocyte colony-stimulating factor and erythropoietin contain the DPP-IV-susceptible N-terminal amino acid sequence with proline in the second position. However, the direct demonstration of the biological significance of DPP-IV-mediated cleavage of hematopoietic cytokines has been elusive. However, recent studies have shown that the biological activities of chemokines can be regulated by the DPPIV-mediated cleavage of their $\mathrm{N}$-terminal region (15-17).

Hematopoiesis is dependent upon the tissue microenvironment, composed of stroma cells, extracellular matrix and cytokines, which can be produced locally or transported to the tissue by circulating biological fluids. The bioavailability of cytokines for the hematopoietic precursors depends upon their input, stability, distribution, and association with the extracellular matrix. Consequently, the presence and catalytic activity of various peptidases can determine the availability of cytokines at a particular site in the hematopoietic environment.

DPP-IV is a membrane-anchored enzyme with its catalytic site in the pericellular environment and it can also be cleaved and released from the cell membrane (18). The cysteine-rich region of DPP-IV contains fibronectin and collagen-binding sites, and the released enzyme can secondarily associate with the extracellular matrix, potentially generating gradients or focal microenvironments with specific enzyme activity (19). In 
view of the fact that $\mathrm{CD} 26$ can both potentially act as a membrane ectoenzyme and be released in a soluble form into the intercellular biological fluids, we have addressed the question of the relative importance and activity of the two forms of DPP-IV in the hematopoietic environment. We have also monitored its activity in stroma cells and in their supernatants. We have found that all the cells studied expressed DPP-IV, whose enzymatic activity was modulated by the cell membrane background and the insertion of the enzyme into membrane lipid rafts.

\section{Material and Methods}

\section{Cell cultures}

All cell lines were obtained from the Rio de Janeiro Cell Bank (PABCAM, Federal University of Rio de Janeiro, Rio de Janeiro, RJ, Brazil). We used the following permanent murine cell lines: a) growth factor-dependent myeloid precursor cell line FDC-P1, b) murine hematopoiesis-supportive bone marrow stroma cell line S17, and c) myoblast cell line $\mathrm{C} 2 \mathrm{C} 12$. The $\mathrm{S} 17$ cell line was used with the authorization of $\mathrm{K}$. Dorshkind (20). The following primary murine cell lines were used: a) normal fetal liver connective tissue cells FF18, b) connective tissue cells isolated from fibrogranulomatous reactions elicited in mouse liver by schistosomal infection, named GR cells, and c) newborn skin fibroblasts (SF). The former two cell types sustain myelopoiesis whilst the last one does not. These cells were isolated, maintained, and characterized as previously described (21-23). Cells were maintained routinely in Dulbecco's minimum essential medium (DMEM; Sigma, St. Louis, MO, USA) supplemented with $10 \%$ fetal bovine serum (FBS; Cultilab, Campinas, SP, Brazil). FDC-P1 cells were maintained in the medium supplemented with the supernatant of the WeHi3B cell line as a source of IL-3.

\section{DPP-IV gene expression}

Total RNA was obtained from cells lysed with Trizol reagent (Gibco-BRL, Gaithersburg, MD, USA), and purified according to the manufacturer's protocol. RNA was transcribed into cDNA using a reverse transcriptase (Gibco-BRL) following the standard protocol. It was amplified by PCR in 40 cycles $\left(92^{\circ} \mathrm{C}\right.$ for $1 \mathrm{~min}, 40^{\circ} \mathrm{C}$ for $1 \mathrm{~min}, 72^{\circ} \mathrm{C}$ for $1 \mathrm{~min}$ ) with primers specific for murine CD26 (5'-ATG GAA TAA CTG ACT GGG TTT ATG A-3' and 5'-TGT ACA GTC TTT CTT ATC TTT CGG G-3') and B-actin (5'GTG GGC CGC TCT AGG CAC CA-3' and 5'-CTC TTT GAT GTC ACG CAC GAT TTC-3'). These CD26 primers amplify the region between the 9th and the 16th exons, between bp 686 and 1284, and provide a product of $599 \mathrm{bp}$. An RT-PCR, in which the reverse transcriptase was omitted in the preparation of the cDNA, was always used as a control in order to monitor possible DNA contamination and amplification of the genomic DNA sequences.

\section{Enzyme kinetics and validation of the experimental model}

The cells were plated onto 24-well culture plates $\left(1 \times 10^{5}\right.$ cells/well $)$, and incubated for $24 \mathrm{~h}$ at $37^{\circ} \mathrm{C}$ under $5 \% \mathrm{CO}_{2}$. Cell monolayers were washed with isotonic $0.1 \mathrm{M}$ Tris$\mathrm{HCl}$ buffer, $\mathrm{pH}$ 7.4, and incubated with the substrate Gly-Pro-p-nitroanilide (Bachem, Torrance, CA, USA) (concentration from 0.2 to $5 \mathrm{mM}$ ) in $0.1 \mathrm{M}$ Tris- $\mathrm{HCl}, \mathrm{pH} 7.4$, final volume $0.2 \mathrm{ml}$, in a rotary shaker bath, at $37^{\circ} \mathrm{C}$ for $1 \mathrm{~h}$. Preliminary assays showed that the relationship between product release and time was linear within $3 \mathrm{~h}$. The reaction was interrupted by adding $0.8 \mathrm{ml} 1 \mathrm{M}$ sodium acetate, $\mathrm{pH}$ 4.4. The negative control of the reaction was prepared by adding sodium acetate buffer before the substrate. After centrifugation for $2 \mathrm{~min}$ at $10,000 \mathrm{~g}$, the absorbance of the supernatant was measured 
spectrophotometrically at $405 \mathrm{~nm}$. Both the reactions and the control assays were carried out in triplicate. Porcine kidney DPP-IV (Sigma) was used as a positive control.

Cell viability during the enzyme kinetic study was monitored by the Trypan blue exclusion assay. S17 cells were plated onto 24-well tissue culture plates (Nunc, Roskilde, Denmark) and maintained until reaching confluence. The cultures were washed and incubated for $1 \mathrm{~h}$ at $37^{\circ} \mathrm{C}$ in a) $0.1 \mathrm{M}$ Tris- $\mathrm{HCl}$ buffer with the highest concentration of the substrate (5 mM Gly-Pro-p-nitroanilide used in the kinetic study, b) the same buffer without the substrate, c) the standard phosphatebuffered calcium-magnesium-free saline solution, d) DMEM, and e) DMEM supplemented with $10 \%$ FBS (each one in triplicate). Cell cultures were washed, trypsinized and incubated with Trypan blue and cell viability was monitored under the microscope. Viability ranged from 88 to $93 \%$ for the first three solutions, and from 91 to $97 \%$ for the last two culture media. The differences between these controls were not significant (Mann-Whitney U-test).

Since the cells were maintained in the presence of FBS prior to the enzyme activity assays, we determined whether the DPP-IV present in the serum could bind to culture dishes or to the cell surface and be responsible for the DPP-IV activity observed. Confluent $\mathrm{S} 17$ cell cultures were prepared in 24well tissue culture plates $\left(10^{5}\right.$ cells/well $)$ and maintained for $24 \mathrm{~h}$ at $37^{\circ} \mathrm{C}$ in DMEM supplemented with $10 \%$ FBS. The cultures were placed on ice and washed twice for $1 \mathrm{~min}$ with Tris-HCl buffer, followed by 30 -s incubation with iced $2 \mathrm{M} \mathrm{NaCl}$ in order to dislodge the noncovalently associated molecules. Subsequently, cells were washed with buffer and the activity of the enzyme was monitored as described. The $K_{\mathrm{M}}$ of DPP-IV was $0.98 \pm 0.093 \mathrm{mM}$ in assays without the 2 $\mathrm{M} \mathrm{NaCl}$ treatment (with a confidence interval of 0.77-1.19 at $\mathrm{P}=0.05$ ), and $1.13 \pm$ $0.088 \mathrm{mM}$ after the $2 \mathrm{M} \mathrm{NaCl}$ treatment (with a confidence interval of $0.93-1.33$ at $\mathrm{P}=$ $0.05)$. The difference was not significant.

Culture flasks $\left(175 \mathrm{~cm}^{2}\right)$ containing cells in confluence were incubated at $37^{\circ} \mathrm{C}$ under $5 \% \mathrm{CO}_{2}$ for $1 \mathrm{~h}$ in DMEM without phenol red, and supplemented with $0.5 \%$ bovine serum albumin. The cell supernatants were filtered, and aliquots of $150 \mu 1$ were used for the enzyme kinetic studies for $2 \mathrm{~h}$, as described above. Fitting of the MichaelisMenten equation to the data obtained in the kinetic studies with the aid of a nonlinear regression computer program (24) provided estimates of $K_{\mathrm{M}}$. The confidence intervals were calculated using the Student $t$-test (considered to be significant at $\mathrm{P}<0.05)(25)$.

\section{Partial purification of DPP-IV and inhibition of enzyme activity by diprotin-A}

To determine the sensitivity of DPP-IV obtained from different cells to inhibition by diprotin-A (Ile-Pro-Ile; Bachem), we carried out a partial purification of the enzyme. S17 cells were maintained in six culture flasks (175 $\mathrm{cm}^{2}$ each) until reaching confluence, and washed with $0.01 \mathrm{M}$ Tris- $\mathrm{HCl}$ buffer, $\mathrm{pH}$ 7.5. Cells were harvested with a rubber policeman and transferred to the centrifuge tube, and the final volume was adjusted to 5 $\mathrm{ml}$ with the same buffer. Cells were submitted to nine freeze and thaw cycles in liquid nitrogen, and centrifuged for $10 \mathrm{~min}$ at 5000 $g$. The floating membrane-containing fraction, the aqueous fraction, and the pellet were harvested and stored for further analysis.

A $2.5-\mathrm{ml}$ aliquot of the membrane fraction was partially purified by liquid chromatography on a $1.2 \mathrm{ml}$ DEAE-Sephacel column washed with $0.1 \mathrm{M}$ Tris-HCl buffer and then equilibrated with $10 \mathrm{mM}$ Tris- $\mathrm{HCl}$ buffer, both $\mathrm{pH}$ 7.5. The column was washed with $6 \mathrm{ml}$ of the latter buffer and eluted with a discontinuous gradient from 0 to $0.4 \mathrm{M}$ $\mathrm{NaCl}(4 \mathrm{ml} /$ fraction) in the same buffer. DPP-IV activity was monitored as described 
above, and the fractions with the highest total activity were pooled and used for further study. For the study of diprotin-A inhibition of the enzyme activity, the samples were incubated with $1.5 \mathrm{mM}$ Gly-Pro-p-nitroanilide and diprotin-A at concentrations ranging from 0 to $10 \mathrm{mM}$, and the enzyme activity was monitored as described above.

\section{Immunoblots}

DPP-IV purified from S17 cells as described above and porcine kidney DPP-IV (Sigma) were blotted onto Hybond-P hydrophobic polyvinylidene difluoride membranes, using a Minifold II blotter (SRC 072/0, Schleicher and Schuell Inc., Keene, NH, USA), 10 or $20 \mu 1$ per slot. The membrane was saturated with Tris-HCl buffer containing $0.15 \mathrm{M} \mathrm{NaCl}, 0.2 \%$ Tween-20 (Sigma), and $5 \%$ skim milk for $1 \mathrm{~h}$ at room temperature in a rotary shaker. The polyclonal goat anti-CD26 antibody (SC-7042, Santa Cruz Biotechnology, Santa Cruz, CA, USA) was diluted 1:200 in the same buffer lacking skim milk, and incubated for $1 \mathrm{~h}$ at room temperature. The membranes were washed 3 x 5 min with the same buffer, followed by incubation with the polyclonal anti-goat immunoglobulin coupled with horseradish peroxidase (Santa Cruz, SC-2020), diluted 1:20,000 for $45 \mathrm{~min}$. After washing, the membranes were incubated for 5 min with the ECL-Plus Western Blotting Detection System (RPN 2132, Amersham-Pharmacia Biotech, Bucks, UK) following the manufacturer's protocols, and exposed to XOMAT 500 RA X-ray film (BRAF, Manaus, AM, Brazil).

\section{Isolation of cell membrane lipid rafts}

Rafts were isolated from S17 cell membranes by the method of Kabouridis et al. (26). Briefly, $5 \times 10^{7}$ cells were washed and treated on ice with a $1 \%$ Triton X-100 solution containing protease inhibitors $(4 \mu \mathrm{g} / \mathrm{ml}$ leupeptin, $10 \mu \mathrm{g} / \mathrm{ml}$ soybean trypsin inhibitor, $100 \mu \mathrm{g} / \mathrm{ml}$ phenylmethylsulfonyl fluoride, $5 \mu \mathrm{g} / \mathrm{ml}$ aprotinin). The suspension was centrifuged on a discontinuous 5, 30 and $40 \%$ sucrose gradient at $200,000 \mathrm{~g}$ at $4^{\circ} \mathrm{C}$ for $15 \mathrm{~h}$. The fraction located at the 5-30\% sucrose gradient interphase, containing low density compounds including membrane rafts, was harvested and compared to the pellet (below the $40 \%$ sucrose solution) that contained the high density compounds. Proteins from both fractions were precipitated with iced acetone for quantification and Western blots. For enzyme activity assays, cells were processed without protease inhibitors. They were centrifuged at $25,000 \mathrm{~g}$ at $4^{\circ} \mathrm{C}$ for $20 \mathrm{~min}$, and the supernatant was harvested and centrifuged at 200,000 $\mathrm{g}$ at $4^{\circ} \mathrm{C}$ for $90 \mathrm{~min}$. The precipitate was harvested and resuspended in $300 \mu 120 \mathrm{mM}$ Tris-HCl buffer, $\mathrm{pH}$ 7.4. The enzyme activity was monitored in $15-\mu 1$ samples as described above.

\section{Results}

\section{Expression of DPP-IV}

The expression of the DPP-IV (or CD26) gene was studied by RT-PCR in connective stroma cells that sustain hematopoiesis or myelopoiesis, i.e., S17 (bone marrow), FF18 (fetal liver) and GR (liver cells isolated from fibrogranulomatous inflammatory reactions), those that do not sustain hematopoiesis, i.e., SF (newborn skin fibroblast), and an unrelated cell line $\mathrm{C} 2 \mathrm{C} 12$ (myoblasts), as well as in the established myeloid precursor cell lineage FDC-P1. The DPP-IV gene was expressed equally in all the cells tested. They produced the single mRNA band, with no alternative splicing in the region between exons 9 and 16 that was amplified by the primers used (Figure 1).

The synthesis of the DPP-IV protein was demonstrated by immunoblotting. Using a commercial CD26 antibody, the partially 
purified enzyme from S17 cells showed a immunoreactivity similar to that observed for the DPP-IV obtained from porcine kidney (Figure 2).
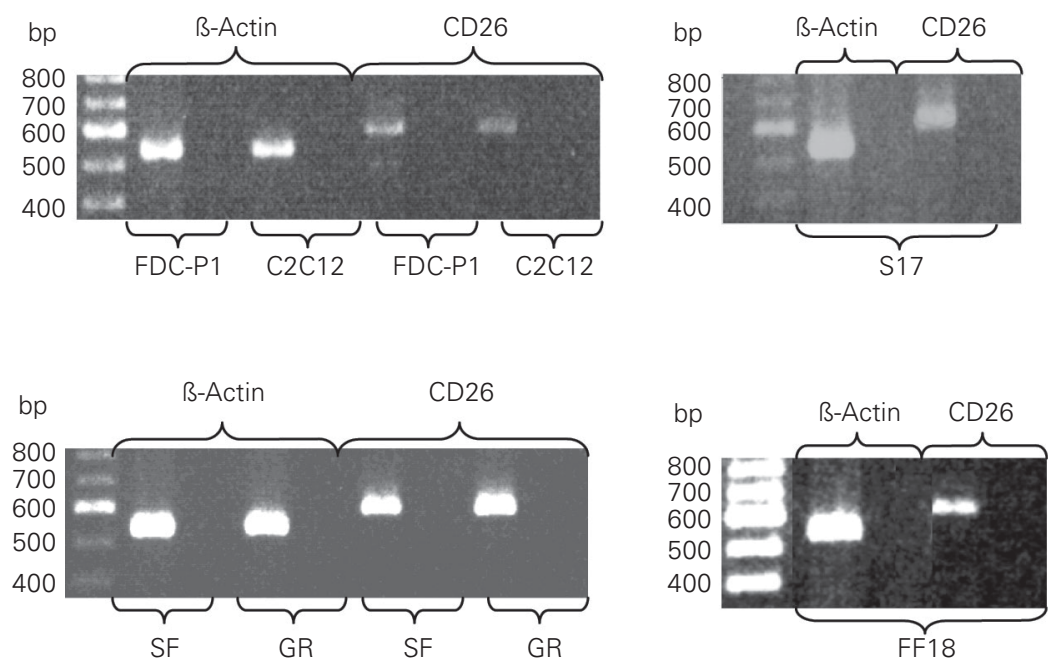

Figure 1. RT-PCR detection of DPP-IV (CD26) expression in the myeloid progenitor cell line FDC-P1, myoblast cell line $\mathrm{C} 2 \mathrm{C} 12$, murine bone marrow stroma cell line S17, primary murine liver cell lines FF18 and GR, and primary murine newborn skin fibroblasts (SF). ßActin expression is used as an internal control.

Figure 2. Immunoblot analysis of DPP-IV (CD26) using commercial polyclonal goat anti-DPP-IV antibody (Santa Cruz). A and B, DPPIV purified from porcine kidney

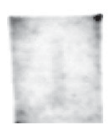

A

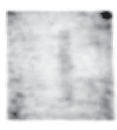

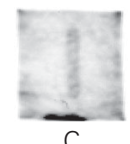

C

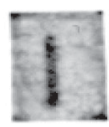

$\mathrm{D}$

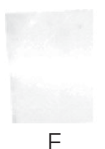

E
$0.4 \mu \mathrm{g}$ and $0.8 \mu \mathrm{g}$; Sigma). $C$ and D, DPP-IV purified from the S17 murine bone marrow stroma cell line $(50$ and $100 \mu \mathrm{g})$. E, negative control for the secondary anti-goat antibody.

Figure 3. Analysis of DPP-IV enzyme kinetics using glycine-proline-p-nitroanilide as substrate. Circles, Enzyme activity of the cell membrane-associated enzyme. Squares, Enzyme activity in the cell culture supernatant. A typical assay is shown, with the curves that represent the best adjustment values for enzyme kinetics calculated from fittings of the Michaelis-Menten equation to the experimental data.

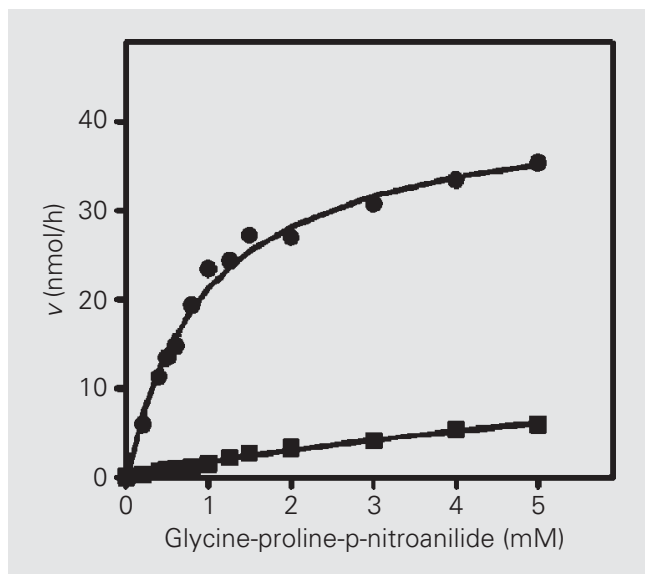

Inhibition of DPP-IV activity by diprotin-A

In order to test the specificity of the proteolytic activity of DPP-IV, we monitored its inhibition by diprotin-A, which is a competitive inhibitor of the enzyme. The maximal inhibition of the DPP-IV activity, obtained with $10 \mathrm{mM}$ inhibitor and $1.5 \mathrm{mM}$ substrate, was $23 \%$ for the total S17 cell extract, $46 \%$ for the S17 cell supernatant, $53 \%$ for the crude S17 membrane fraction, $80 \%$ for the protein partially purified on a DEAE-Sephacel column, and $100 \%$ for the purified porcine kidney DPP-IV. The partial inhibition in the nonpurified extracts was probably due to the presence of other proteases, which may hydrolyze the inhibitor, or of other molecules that may bind to the inhibitor. The presence of other enzymes that specifically cleave the substrate at the Pro-anilide bond is not probable, in view of the absence of this type of activity in DEAESephacel-purified fractions other than the one containing DPP-IV (data not shown).

\section{DPP-IV activity depends on the cell membrane environment}

The saturation curve of DPP-IV (Figure 3) was analyzed and showed differences between the membrane-associated and released enzymes. The observed apparent $K_{\mathrm{M}}$ and the confidence intervals showed also that the $K_{\mathrm{M}}$ were not the same for all the assayed cell lines (Table 1). S17 cells and all the primary cell lines obtained from connective tissue stromas showed similar apparent $K_{\mathrm{M}}$ values, with no clear difference between those that sustain hemato- or myelopoiesis (bone marrow and liver) or do not (skin). The apparent $K_{\mathrm{M}}$ of myeloid progenitors was within the same magnitude range. The apparent $K_{\mathrm{M}}$ of myoblasts (C2C12 cells) was significantly different from those observed for the connective tissue stromas, indicating that the membrane environment relevant for the enzyme affinity is tissue specific. 
Upon the spontaneous release of DPP-IV into the cell supernatant, the kinetics of its hydrolysis of Gly-Pro-p-nitroanilide was considerably modified, with the $K_{\mathrm{M}}$ being larger roughly by one order of magnitude. These differences were statistically significant, as shown by analysis of the intervals of confidence (Table 1). The enzyme released by myoblasts was again significantly different from those released from connective tissue stromas and myeloid cells, with the $K_{\mathrm{M}}$ of myoblast DPP-IV being only slightly different under such conditions.

\section{Dependence of DPP-IV activity on the environment}

Our previous studies, as well as studies from other laboratories, have shown that the ability of a stroma to sustain myelopoiesis depends upon the stroma-associated glycoconjugates, and glycosaminoglycans in particular $(23,27-29)$. In order to determine whether the differences in the $K_{\mathrm{M}}$ values for membrane-bound versus spontaneously released DPP-IV were a consequence of the loss of interactions of the enzyme with the cell membrane-associated molecules such as proteoglycans, we first assayed the effect of sulfated glycosaminoglycans on the stroma-derived enzyme $K_{\mathrm{M}}$. Heparin had no effect on the activity of DPP-IV anchored to the hematopoietic stroma cell membrane, or on the activity of DPP-IV purified from porcine kidney (Figure 4A,B). Conversely, both heparin and heparan sulfate reduced the apparent $K_{\mathrm{M}}$ of stroma-derived enzymes in the soluble form apparently in a concentrationdependent manner (Figure 4C,D). An inverse linear relationship was obtained between the molecular mass and the glycosaminoglycan concentration in the solution that elicited a maximal modification of the enzyme affinity (Figure 5). In view of the fact that DPP-IV is a highly glycosylated membrane-anchored molecule, we further questioned whether the molecular structure and the presence of negative charges on the assayed glycoconjugates was determinant for their modulation of DPP-IV activity. This was apparently not the case, since dextran sulfate and nonsulfated dextran had similar effects in increasing the $K_{\mathrm{M}}$ of the enzyme, as also did smaller sugars such as sucrose and trehalose that are also known to organize the water molecules (30) (Table 2). These results were supported in assays using the treatment of S17 cells with chlorate that inhibits glycosaminoglycan sulfation, or treatment with heparitinase prior to monitoring the enzyme activity. In both cases there was no effect on the apparent DPP-IV $K_{\mathrm{M}}$ under such experimental conditions (data not shown). Taken together, these experiments suggested that DPP-IV affinity was dependent upon the environment, which provided an optimal relationship between the enzyme and the substrates.

Since being attached to the cell membrane provided conditions for a low apparent $K_{\mathrm{M}}$ of DPP-IV, we questioned whether

Table 1. Apparent $K_{\mathrm{M}}$ for dipeptidyl peptidase IV (DPP-IV) activity in the cell layer and released in the soluble form into the supernatants of cell cultures.

\begin{tabular}{|c|c|c|c|c|}
\hline & \multicolumn{2}{|c|}{$\begin{array}{l}\text { DPP-IV bound to the } \\
\text { cell membrane }\end{array}$} & \multicolumn{2}{|c|}{$\begin{array}{l}\text { DPP-IV released in } \\
\text { a soluble form }\end{array}$} \\
\hline & $K_{\mathrm{M}}(\mathrm{mM})^{\mathrm{a}}$ & $\mathrm{Cl}$ & $K_{\mathrm{M}}(\mathrm{mM})^{\mathrm{a}}$ & $\mathrm{Cl}^{\mathrm{b}}$ \\
\hline \multicolumn{5}{|c|}{ Murine bone marrow } \\
\hline S17 & $0.98 \pm 0.093$ & $0.77-1.19$ & $8.86 \pm 0.93$ & $5.02-12.69$ \\
\hline \multicolumn{5}{|c|}{ Murine liver } \\
\hline FF18 & $0.53 \pm 0.074$ & $0.37-0.70$ & $8.44 \pm 0.66$ & $6.97-9.92$ \\
\hline GR & $0.63 \pm 0.102$ & $0.40-0.85$ & $7.95 \pm 1.34$ & $4.99-10.91$ \\
\hline \multicolumn{5}{|c|}{ Murine skin } \\
\hline SF & $0.82 \pm 0.059$ & $0.69-0.96$ & $6.76 \pm 0.80$ & $4.97-8.56$ \\
\hline \multicolumn{5}{|c|}{ Myeloid precursor } \\
\hline FDC-P1 & $0.74 \pm 0.069$ & $0.59-0.90$ & $8.64 \pm 1.37$ & $5.58-11.69$ \\
\hline \multicolumn{5}{|c|}{ Murine myoblasts } \\
\hline $\mathrm{C} 2 \mathrm{C} 12$ & $1.49 \pm 0.082$ & $1.31-1.67$ & $2.78 \pm 0.26$ & $2.18-3.37$ \\
\hline
\end{tabular}


Figure 4. Determination of $K_{M}$ for DPP-IV (CD26) in the presence of heparin or heparan sulfate. A, DPP-IV associated with S17 cell membranes in the presence of heparin (0 to $10 \mu \mathrm{g} / \mathrm{ml}$ ). $B$, DPP-IV purified from porcine kidney (Sigma) in the presence of heparin (0 to $16 \mu \mathrm{g} / \mathrm{ml}$ ). C, DPP-IV in the supernatant of S17 cell cultures in the presence of heparin (0 to $100 \mu \mathrm{g} / \mathrm{ml}$ ). D, DPPIV in the supernatant of S17 cell cultures in the presence of heparan sulfate ( 0 to $10 \mu \mathrm{g} / \mathrm{ml}$ ).
Figure 5. Linear inverse ratio between the concentration of the assayed glycosaminoglycans (GAG) that gave the maximal modification of the DPP-IV $K_{\mathrm{M}}$ when assayed in the supernatant of S17 cells and their molecular mass.
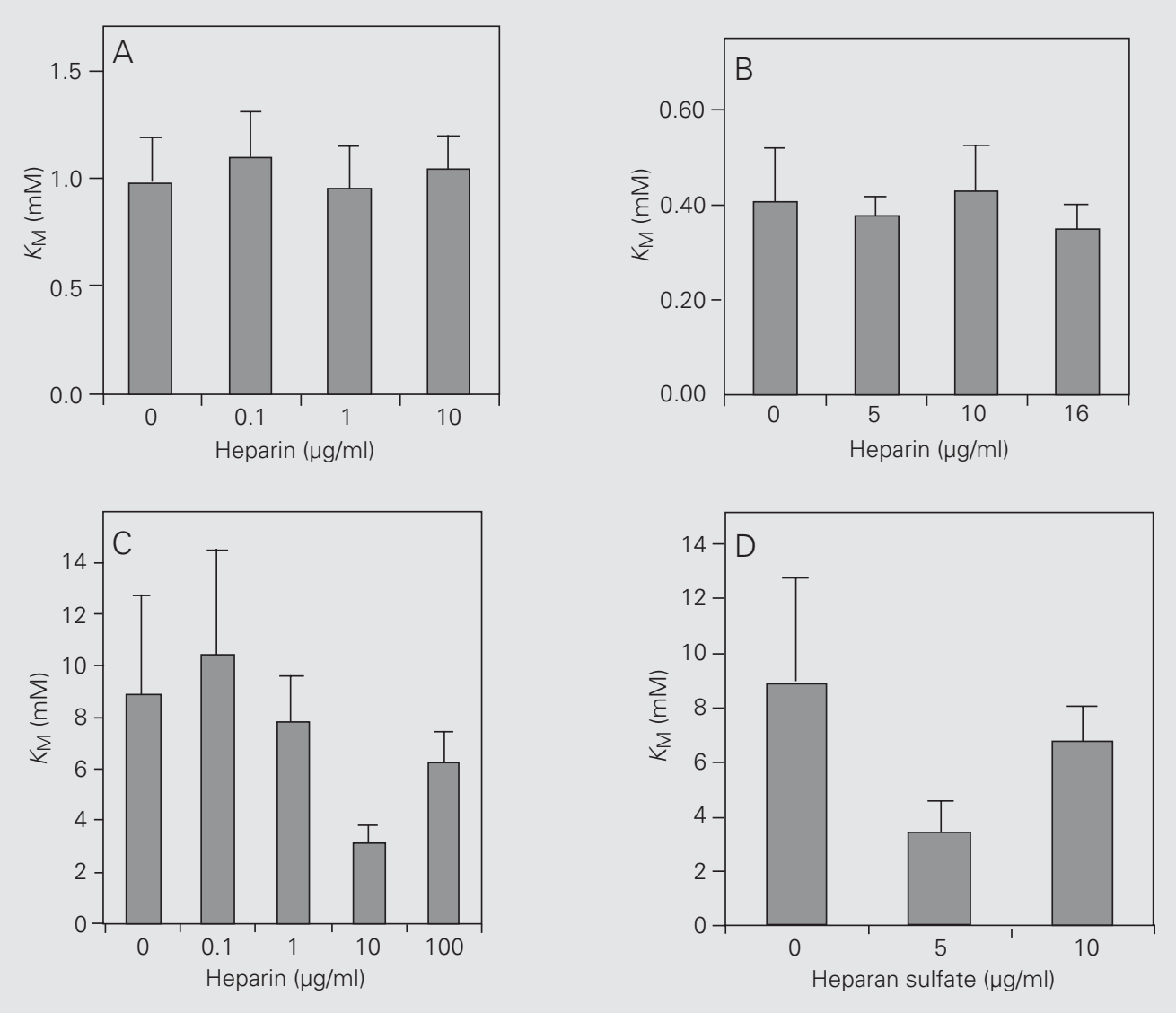

in the cell extract prepared on ice, rich in lipid rafts, where the enzyme velocity attained $18.6 \pm 1.6 \mathrm{nmol} / \mathrm{h}$, while in extracts prepared at room temperature in which lipid rafts were dissolved it was $5.1 \pm 0.2 \mathrm{nmol} / \mathrm{h}$. Moreover, the apparent $K_{\mathrm{M}}$ of DPP-IV in the raft-enriched extract was very low, roughly three times lower than that observed for intact cell membranes, and more than one order of magnitude lower than the one observed in the cell supernatant (Table 3).

Taken together, these data indicate that DPP-IV is located in specialized microdomains on membranes of the connective tissue stromas, the lipid membrane rafts, which provide the molecular environment required and sufficient for optimal enzyme activity.

\section{Discussion}

We demonstrated the peptidolytic activity 
of DPP-IV in all the cell cultures studied, including the connective tissue stromas of bone marrow and liver that sustain hematopoiesis in vitro, skin fibroblasts that do not, a myeloid progenitor cell line, and unrelated cells such as myoblasts. Furthermore, we showed that DPPIV mRNA was expressed in various tissues. The mouse DPP-IV gene is approximately 90 $\mathrm{kb}$ long, comprises 26 exons, and an alternative splicing of DPP-IV has not been reported $(31,32)$. Accordingly, our data show that the observed peptidase activity corresponded to expression of the DPP-IV gene in all the murine cell lines studied. A single mRNA band was observed by RT-PCR analysis, showing that in all the cells studied the enzyme is a product of a single gene with no alternative splicing under the conditions used, and within the limits of the RT-PCR-amplified fragment. The immunoreactivity of the protein purified from the S17 cell extract was compared with that of the porcine kidney DPP-IV, and both proteins were recognized by the commercially available antibody for CD26.

In contrast to the homogeneity of the enzyme expression, we show that the DPPIV apparent $K_{\mathrm{M}}$ depended upon whether the enzyme was membrane bound or released from the membrane. The apparent $K_{\mathrm{M}}$ was significantly different and dependent upon the tissue origin of the cells studied. When DPP-IV was released from the cell membrane environment, its apparent $K_{\mathrm{M}}$ increased by one order of magnitude in murine connective tissue stromas and myeloid cells, but only doubled in myoblasts. The apparent $K_{\mathrm{M}}$ does not depend upon the total quantity of the assayed enzyme and indirectly reflects the relative affinity of the enzyme for a given substrate. Although the assayed substrate is an artificial one and does not necessarily reflect the affinity of the enzyme for potential natural substrates, the observed differences in the apparent $K_{\mathrm{M}}$ for diverse molecular backgrounds indicated that the enzyme affinity was modulated by the associated molecules.

DPP-IV is a highly sialylated glycopro- tein, and inactivation of a single $\mathrm{N}$-glycosylation site resulted in changes of enzymatic activity, subcellular localization, and biological stability of the protein $(33,34)$. The $\mathrm{T}$ cell membrane-bound DPP-IV is a homodimer, with two chains of $110 \mathrm{kDa}$ molecular mass. The soluble form is produced by proteolytic cleavage, and several molecular forms have been reported to be present in the human serum $(35,36)$. The activity of DPP-

Table 2. Effect of glycosaminoglycans and sugars on the $K_{M}$ of dipeptidyl peptidase IV (DPP-IV) in S17 cells.

\begin{tabular}{|c|c|c|}
\hline Conditions & $K_{\mathrm{M}}(\mathrm{mM})^{\mathrm{a}}$ & $\mathrm{Cl}^{\mathrm{b}}$ \\
\hline $\begin{array}{l}\text { DPP-IV bound to the } \\
\text { membrane of } \mathrm{S} 17 \text { cells }\end{array}$ & $0.98 \pm 0.093$ & $0.77-1.19$ \\
\hline $\begin{array}{l}\text { DPP-IV released from S17 cells } \\
\text { in the soluble form }\end{array}$ & $8.86 \pm 0.93$ & $5.02-12.69$ \\
\hline $\begin{array}{l}\text { DPP-IV released from S17 cells in } \\
\text { the presence of heparin }(10 \mu \mathrm{g} / \mathrm{ml})\end{array}$ & $3.06 \pm 0.34$ & $2.32-3.81$ \\
\hline $\begin{array}{l}\text { DPP-IV released from } S 17 \text { cells in } \\
\text { the presence of heparan sulfate }(5 \mu \mathrm{g} / \mathrm{ml})\end{array}$ & $3.34 \pm 0.47$ & $2.30-4.39$ \\
\hline $\begin{array}{l}\text { DPP-IV released from } S 17 \text { cells in } \\
\text { the presence of dextran sulfate }(0.25 \mu \mathrm{g} / \mathrm{ml})\end{array}$ & $4.62 \pm 0.53$ & $3.43-5.81$ \\
\hline $\begin{array}{l}\text { DPP-IV released from S17 cells in } \\
\text { the presence of chondroitin sulfate }(2 \mu \mathrm{g} / \mathrm{ml})\end{array}$ & $3.89 \pm 0.37$ & $3.07-4.70$ \\
\hline $\begin{array}{l}\text { DPP-IV released from S17 cells in } \\
\text { the presence of dextran }(0.8 \mu \mathrm{g} / \mathrm{ml})\end{array}$ & $4.81 \pm 0.39$ & $3.95-5.68$ \\
\hline $\begin{array}{l}\text { DPP-IV released from S17 cells in } \\
\text { the presence of trehalose }(320 \mu \mathrm{g} / \mathrm{ml})\end{array}$ & $5.00 \pm 0.71$ & $3.11-6.59$ \\
\hline $\begin{array}{l}\text { DPP-IV released from S17 cells in } \\
\text { the presence of sucrose }(350 \mu \mathrm{g} / \mathrm{ml})\end{array}$ & $5.15 \pm 0.42$ & $4.20-6.08$ \\
\hline
\end{tabular}

The concentrations of saccharide that gave the maximum effect on $K_{\mathrm{M}}$ are reported. Data are reported as means \pm SEM.

a Determined from fitting the Michaelis-Menten equation to data obtained from kinetic studies.

${ }^{b} \mathrm{Cl}$, confidence interval calculated by the Student $t$-test $(P=0.05)$.

Table 3. The apparent $K_{\mathrm{M}}$ for dipeptidyl peptidase IV (DPP-IV) from hematopoietic stroma cells.

\begin{tabular}{lll}
\hline Stroma-derived DPP-IV & \multicolumn{1}{c}{$K_{\mathrm{M}}(\mathrm{mM})^{\mathrm{a}}$} & \multicolumn{1}{c}{$\mathrm{Cl}$} \\
\hline Bound to cell membrane & $0.98 \pm 0.093$ & $0.77-1.19$ \\
Released in a soluble form & $8.86 \pm 0.93$ & $5.02-12.69$ \\
Cell membrane preparations enriched with & $0.29 \pm 0.027$ & $0.23-0.35$ \\
$\quad$ lipid rafts & & \\
\hline
\end{tabular}

Data are reported as means \pm SEM

a Determined from fitting the Michaelis-Menten equation to data obtained in kinetic studies.

${ }^{b} \mathrm{Cl}$, confidence interval calculated by the Student $t$-test $(P=0.05)$. 
IV purified from serum has a $K_{\mathrm{M}}$ value of $0.22 \mathrm{mM}$ for the Gly-Pro-p-nitroanilide substrate, similar to that of the membrane-bound DPP-IV purified from T cells (37), suggesting that the glycosylation or release from the cell membrane did not modify the enzyme $K_{\mathrm{M}}$ in this cell type. In contrast, our studies showed a considerable modification in apparent $K_{\mathrm{M}}$ when DPP-IV was released spontaneously from the pericellular environment of connective tissue stromas into the supernatant. Addition of hydrophilic molecules could partially reverse the loss of affinity, in a well-defined range of their ratio with DPPIV. This suggested the existence of ordered supramolecular membrane structures in which DPP-IV acts on the pericellular environment. Indeed, extraction of cell membranes by a method that preserved the organization of membrane lipid rafts was sufficient to fully preserve the affinity of DPP-IV observed on intact cells. DPP-IV was reported to be integrated into lipid rafts on lymphocytes, but not on epithelial cells $(38,39)$. Targeting of DPP-IV to rafts is required for stimulation of $\mathrm{T}$ cells, albeit its enzyme activity is not (40), with the possibility that the enzymatic activity released from lymphocytes that fully preserves its substrate affinity is an independent enzyme pool, not related to lipid rafts. In our study, the enzyme fraction inserted into lipid rafts had a lower $K_{\mathrm{M}}$ than the total enzyme in intact membranes. We understand that this may also indicate the presence of two membrane pools, one in lipid rafts with the optimal substrate affinity, and the other dispersed in the membrane with a lower affinity. Alternatively, the presence of membrane-associated molecules not participating in rafts, which are absent in raft-enriched fractions, may interfere with the optimal enzyme affinity.

Our study suggests that, in the hematopoietic environment, DPP-IV activity is essentially associated with short-range controls which are dependent upon the stroma cell membrane organization and direct cell-cell interactions, while long-range controls depending upon soluble enzyme forms are less probable in view of the low catalytic activity of the enzyme. Simultaneously, the released enzyme can act by interaction with other molecular systems that do no require its catalytic activity, such as adenosine deaminase binding. This is in keeping with the concept of microenvironmental niches in the bone marrow environment with rigorously controlled cell-cell interactions, which can retain early progenitors in a low-cycling state, whilst the more mature ones follow commitment and intense production of specific cell lineages in a highly ordered and programmed pattern.

It is generally accepted that DPP-IV is a product of a single gene. The highly divergent enzymatic behavior of DPP-IV is understandable in the context of the membrane background, since supramolecular complexes in lipid rafts are known to be required for optimal molecular activity in transduction pathways and cell activation. However, the spontaneously released DPP-IV molecule is cleaved at a conserved site close to the membrane, fully preserving the structure of its catalytic site. It is thus surprising that in hematopoietic and connective tissues the enzyme release is associated with such a great loss of affinity, not observed in myoblasts, lymphocytes or kidney extract. Post-translational modifications of DPP-IV may be determinant for the wide tissue-specific differences in its membrane location and enzyme kinetics, such as observed in the present study, and they are the subject of ongoing studies.

\section{Acknowledgments}

We are grateful to Ivarne L.S. Tersariol, Universidade de Mogi das Cruzes, Mogi das Cruzes, SP, Brazil, for a generous supply of purified heparin and heparan sulfate, and to Enrique Guillermo Oestreicher Abarzúa, Instituto de Química, Universidade Federal do Rio de Janeiro, Rio de Janeiro, RJ, Brazil, for help in analysis of enzyme kinetic data. 


\section{References}

1. Hong WJ, Petell JK, Swank D, Sanford J, Hixson DC \& Doyle D (1989). Expression of dipeptidyl peptidase IV in rat tissues is mainly regulated at the mRNA levels. Experimental Cell Research, 182: 256-266

2. Tsugiki M, Kobayashi Y, Kawasaki T \& Yoshimi T (1998). Identification of bile canalicular cell surface antigen HAM.4 as dipeptidyl peptidase IV (DPPIV) and characterization of its role in hepatic regeneration after partial hepatectomy in rats. Digestive Diseases and Sciences, 43: 2591-2600.

3. Levy MT, McCoughan GW, Abbott CA, Park JE, Cunningham AM, Muller E, Rettig WJ \& Gorrell MD (1999). Fibroblast activation protein: a cell surface dipeptidyl peptidase and gelatinase expressed by stellate cells at the tissue remodelling interface in human cirrhosis. Hepatology, 29: 1768-1778.

4. Hopsu-Havu VK \& Glaner GG (1966). A new dipeptide naphthylamidase hydrolyzing glycyl-prolyl-ß-naphthylamide. Histochimie, 7: 197201.

5. Hegen M, Niedobitek G, Klein CE, Stein H \& Fleischer B (1990). The T cell triggering molecule Tp103 is associated with dipeptidyl aminopeptidase IV activity. Journal of Immunology, 144: 2908-2914.

6. Torimoto Y, Dang NH, Vivier E, Tanaka T, Schlossman SF \& Morimoto C (1991). Coassociation of CD26 (dipeptidyl peptidase IV) with CD45 on the surface of human T lymphocytes. Journal of Immunology, 147: 2514-2517.

7. Hegen M, Kameoka J, Dong RP, Schlossman SF \& Morimoto C (1997). Cross-linking of CD26 by antibody induces tyrosine phosphorylation and activation of mitogen-activated protein kinase. Immunology, 90: 257-264

8. Dong RP, Kameoka J, Hegen M, Tanaka T, Xu Y, Schlossman SF \& Morimoto C (1996). Characterization of adenosine deaminase binding to human CD26 on T cells and its biologic role in immune response. Journal of Immunology, 156: 1349-1355.

9. Bristol LA, Sakaguchi K, Appella E, Doyle D \& Takács L (1992). Thymocyte costimulating antigen is CD26 (dipeptidyl-peptidase IV): Co-stimulation of granulocyte, macrophage, and T lineage cell proliferation via CD26. Journal of Immunology, 149: 367-372.

10. Bristol LA, Bachvshin W \& Takács L (1995). Inhibition of CD26 enzyme activity with Pro-boropro stimulates rat granulocyte/macrophage colony formation and thymocyte proliferation in vitro. Blood, 85: 3602-3609.

11. Scholz W, Mentlein R, Heymann E, Feller AC, Ulmer AJ \& Flad H (1985). Interleukin 2 production by human T lymphocytes identified by antibodies to dipeptidyl peptidase IV. Cellular Immunology, 93: 199-211.

12. Schön E \& Ansorge S (1990). Dipeptidyl peptidase IV in the immune system. Biological Chemistry Hoppe-Seyler, 371: 699-705.

13. Holst JJ \& Deacon CF (1998). Inhibition of the activity of dipeptidylpeptidase IV as a treatment for type 2 diabetes. Diabetes, 47: 16631670.

14. Augustyns K, Bal G, Thonus G, Belyaev A, Zhang XM, Bollaert W, Lambier AM, Durinx C, Goossens F \& Haemers A (1999). The unique properties of dipeptidyl-peptidase IV (DPP IV/CD26) and the therapeutic potential of DPP IV inhibitors. Current Medicinal Chemistry, 6: 311-327.

15. Oravecz T, Pall M, Roderiquez G, Gorrell MD, Ditto M, Nguyen NY, Boykins R, Unsworth E \& Norcross MA (1997). Regulation of the receptor specificity and of the function of the chemokine RANTES by dipeptidyl peptidase IV (CD-26)-mediated cleavage. Journal of Experimental Medicine, 186: 1865-1872.
16. Van Coillie E, Proost P, Van Aelst I, Struyf S, Polfliet M, De Meester I, Harvey DJ, Van Damme J \& Opendakker G (1998). Functional comparison of two human monocyte chemotatic protein-2 isoforms, roles of the amino-terminal pyroglutamic acid and processing by CD26/dipeptidyl peptidase IV. Biochemistry, 37: 12672-12680.

17. Lambier AM, Proost P, Durinx C, Bal G, Senten K, Augustyns K, Schrape S, Van Damme J \& De Meester I (2001). Kinetic investigation of chemokine truncation by CD26/dipeptidyl peptidase IV reveals a striking selectivity within the chemokine family. Journal of Biological Chemistry, 276: 29839-29845.

18. Iwaki-Egawa S, Watanabe $Y$ \& Fujimoto $Y$ (1998). Dipeptidyl peptidase IV from human serum: purification, characterization, and $\mathrm{N}$ terminal amino acid sequence. Journal of Biochemistry, 124: 428433.

19. Loster K, Zeilinger K, Schuppan D \& Reuter W (1995). The cysteinerich region of dipeptidyl peptidase IV (CD26) is the collagen-binding site. Biochemical and Biophysical Research Communications, 217: 341-348.

20. Collins LS \& Dorshkind K (1987). A stromal cell line from myeloid long-term bone marrow culture can support myelopoiesis and B lymphopoiesis. Journal of Immunology, 138: 1082-1087.

21. Alvarez-Silva M \& Borojevic R (1996). GM-CSF and IL-3 activities in schistosomal liver granulomas are controlled by stroma-associated heparan-sulfate proteoglycans. Journal of Leukocyte Biology, 59: 435-441.

22. Dutra HS, Rossi MID, Azevedo SP, El-Cheikh MC \& Borojevic R (1997). Haematopoietic capacity of colony-forming cells mobilized into hepatic inflammatory reactions as compared to that of normal bone marrow cells. Research in Immunology, 148: 437-444.

23. Carvalho MA, Arcanjo K, Silva LCF \& Borojevic R (2001). The capacity of connective tissue stromas to sustain myelopoiesis depends both upon the growth factors and the local intercellular environment. Biology of the Cell, 92: 605-614.

24. Paiva LMC, Pinto GF \& Oestreicher EG (1991). Inhibition of horse liver alcohol dehydrogenase and rabbit muscle lactate dehydrogenase by phenylhydrazine. Biomedica Biochimica Acta, 50: 25-29.

25. Metzler CM (1981). Statistical properties of kinetics estimates. In: Endrenyi L (Editor), Kinetic Data Analysis: Design and Analysis of Enzyme and Pharmacokinetic Experiments. Plenum Press, New York, NY, USA, 25-37.

26. Kabouridis PS, Magee AI \& Ley SC (1997). S-acylation of LCK protein tyrosine kinase is essential for its signaling function in T lymphocytes. EMBO Journal, 16: 4983-4998.

27. Alvarez-Silva M, Silva LC \& Borojevic R (1993). Cell membraneassociated proteoglycans mediate extramedullar myeloid proliferation in granulomatous inflammatory reactions to schistosome eggs. Journal of Cell Science, 104: 477-484.

28. Alvarez-Silva M, Pinazo AC, El-Cheikh MC \& Borojevic R (1994). Myelopoietic competence of stroma composed of hepatic granuloma-derived connective tissue cells or skin fibroblasts. Brazilian Journal of Medical and Biological Research, 27: 2143-2152.

29. Gupta P, Oegema TR, Brazil JJ, Dudek AZ, Slungaard A \& Verfaillie CM (1998). Structurally specific heparan sulfates support primitive human hematopoiesis by formation of a multimolecular stem cell niche. Blood, 92: 4641-4651.

30. Panek AD (1995). Trehalose metabolism - new horizons in technological applications. Brazilian Journal of Medical and Biological Research, 28: 169-181.

31. Marguet D, Bernard AM, Vivier I, Darmoul D, Naquet P \& Pierres M 
(1992). cDNA cloning for mouse thymocyte-activating molecule: A multifunctional ectodipeptidyl peptidase IV (CD26) included in a subgroup of serine proteases. Journal of Biological Chemistry, 267: 2200-2208.

32. Bernard AM, Mattei MG, Pierres M \& Marguet D (1994). Structure of the mouse dipeptidyl peptidase IV (CD26) gene. Biochemistry, 33: 15204-15214

33. Fan H, Meng W, Kilian C, Grams S \& Reutter W (1997). Domainspecific N-glycosylation of the membrane glycoprotein dipeptidylpeptidase IV (CD26) influences its subcellular trafficking, biological stability, enzyme activity and protein folding. European Journal of Biochemistry, 246: 243-251.

34. Smith RE, Talhouk JW, Brown EE \& Edgar SE (1998). The significance of hypersialylation of dipeptidyl peptidase IV (CD26) in the inhibition of its activity by tat and other cationic peptides. CD26: A subverted adhesion molecule for HIV peptide binding. AIDS Research and Human Retroviruses, 14: 851-868.

35. Duke-Cohan JS, Morimoto C, Rocker JA \& Schlossman SF (1995). A novel form of dipeptidylpeptidase in human serum. Isolation, characterization, and comparison with $\mathrm{T}$ lymphocyte membrane dipeptidase IV (CD26). Journal of Biological Chemistry, 270: 14107-14114.

36. Kähne T, Kröning H, Thiel U, Ulmer AJ, Flad HD \& Ansorge S (1996).
Alteration in structure and cellular localization of molecular forms of DPP IV/CD26 during cell activation. Cellular Immunology, 170: 6370.

37. Morimoto C \& Schlossman SF (1998). The structure and function of CD26 in the T-cell immune response. Immunological Reviews, 161: $55-70$

38. Ilangumaran S, Briol A \& Hoessli DC (1997). Distinct interactions among GPI-anchored, transmembrane and membrane associated intracellular proteins and sphingolipids in lymphocyte and endothelial cell plasma membranes. Biochimica et Biophysica Acta, 1328: 227-236.

39. Ait Slimane T, Lenoir C, Bello V, Delaunay JL, Goding JW, Chwetzoff S, Maurice M, Fransen JA \& Trungan G (2001). The cytoplasmic/ transmembrane domain of dipeptidyl peptidase IV, a type II glycoprotein, contains an apical targeting signal that does not specifically interact with lipid rafts. Experimental Cell Research, 270: 45-55.

40. Ishii T, Ohnuma K, Murakami A, Takasawa N, Kobayashi S, Dang NH, Schlossman SF \& Morimoto C (2001). CD26-mediated signaling for $T$ cell activation occurs in lipid rafts through its association with CD45RO. Proceedings of the National Academy of Sciences, USA, 98: $12138-12143$ 